\title{
ENTOMOLOGICAL FAUNA FROM RESERVA BIOLÓGICA DO ATOL DAS ROCAS, RN, BRAZIL: I. MORPHOSPECIES COMPOSITION
}

\author{
ALMEIDA, C. E. de, ${ }^{1,2}$ MARCHON-SILVA, V., RIBEIRO, R., ${ }^{2}$ SERPA-FILHO, A., ${ }^{3}$ ALMEIDA, \\ J. R. de ${ }^{4}$ and COSTA, J. ${ }^{2}$ \\ ${ }^{1}$ Departamento de Museologia, Centro Universitário de Barra Mansa, Rua Vereador Pinho de Carvalho, 267, \\ CEP 27330-550, Barra Mansa, RJ, Brazil \\ ${ }^{2}$ Núcleo de Informatização, Coleção Entomológica, Departamento de Entomologia, IOC-FIOCRUZ \\ ${ }^{3}$ Coleção Entomológica, Departamento de Entomologia, IOC-FIOCRUZ \\ ${ }^{4}$ COPPE, Universidade Federal do Rio de Janeiro \\ Correspondence to: Carlos Eduardo de Almeida, Departamento de Entomologia, Pav. Carlos Chagas, 4ํㅜ \\ andar, Instituto Oswaldo Cruz, FIOCRUZ, Av. Brasil, 4365, CEP 21045-900, Manguinhos, RJ, Brazil, \\ e-mail: calmeida@nitmtecnet.com.br \\ Received January 27, 1999 - Accepted June 22, 1999 - Distributed May 31, 2000
}

(With 1 figure)

\begin{abstract}
Atol das Rocas, the unique atoll in the South-western Atlantic, is located 144 nautical miles $(266 \mathrm{Km})$ northeast from the city of Natal, NE Brazil and 80 nautical miles from Arquipélago de Fernando de Noronha, with geographic co-ordinates $3^{\circ} 51^{\prime} \mathrm{S}$ and $33^{\circ} 49^{\prime \prime} \mathrm{W}$. It's of volcanic origin and coralline formation. The reef is ellipsoid, its largest axis (E-W) is approximately $3.7 \mathrm{~km} \mathrm{long}$, and the shortest $(\mathrm{N}-\mathrm{S})$ is $2.5 \mathrm{~km}$. Inside the lagoon, there are two islands: the Ilha do Farol and Ilha do Cemiterio, which comprehend $7.2 \mathrm{Km}^{2}$ of emerged area. The Atol das Rocas lodges 143,000 birds, mainly by Sula dactilatra, S. leucogaster, Anous stolidus, A. minuta and Sterna fuscata. Due to their remote location, the islands remain largely undisturbed by the human activities. Aiming to a first characterization of the entomological diversity and the general trophic niches of atoll's entomofauna, three collects were made (1994, 1995 and 1996) utilizing several methods for a wide sample. One thousand six hundred and six insect specimens were collected belonging to eight orders: 1 . Coleoptera -333 individuals of Dermestidae (Dermestes cadaverinus); Tenebrionidae (Phaleria testacea and morphospecies) and Curculionidae (one morphospecies); 2. Dermaptera - 50 individuals of Carcinophoridae (Anisolabis maritima); 3. Diptera - 281 individuals of Ephydridae (Scatella sp. and Hecamede sp.) and Hippoboscidae (one morphospecies); 4. Hymenoptera - 45 individuals of Formicidae (Brachymyrmex sp.); 5. Lepidoptera - 111 individuals of Microlepidoptera (one morphospecies); 6. Mallophaga - 18 individuals in birds (two morphospecies); 7. Orthoptera - 237 individuals of Acrididae (Schistocerca cancellata), Tridactylidae (one morphospecies) and Blattidae (three morphospecies); 8 . Thysanoptera 531 individuals (one morphospecies). Also were collected 112 individuals of Arachnida. The taxa of the Order Araneae were represented by the families: 1. Miturgidae (Cheiracanthium inclusum); 2. Salticidae (two morphospecies) and 3. Segestriidae (Ariadna sp.); 4. Theridiidae (Achaearanea sp. and Latrodectus geometricus). For the Order Scorpionida, only samples of Buthidae (Isometrus maculatus) were collected. Through field observations, it was concluded the most insects are detritophagous and/ or necrophagous. It is suggested that which the dimension of ecological niches of the insects are a function of the droppings, trash and corpses of birds. A low diversity in the entomofauna of atoll, with its 25 morphospecies, was ascertained.
\end{abstract}

Key words: Atol das Rocas, entomological fauna of islands, trophic niche. 


\section{RESUMO}

\section{Fauna entomológica da reserva biológica do Atol das Rocas, RN, Brasil: I. Composição de morfoespécies}

O Atol das Rocas é o único atol do Atlântico Sul Ocidental e está situado a 144 milhas náuticas (266 Km) a nordeste da cidade de Natal (RN), NE, Brasil, e a 80 milhas náuticas a oeste do Arquipélago de Fernando

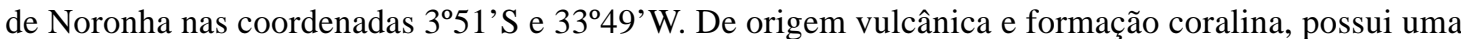
estrutura ligeiramente elipsoidal, quase circular em seu eixo maior (E-W) com cerca de 3,7 Km e o menor $(\mathrm{N}-\mathrm{S})$ tem cerca de $2,5 \mathrm{~km}$. No interior do anel recifal encontram-se duas ilhas, a do Farol e a do Cemitério, que somam 7,2 Km² de área emersa. O Atol das Rocas abriga cerca de 143.000 aves de cinco espécies mais abundantes: Sula dactilatra, S. leucogaster, Anous stolidus, A. minuta e Sterna fuscata. Devido à remota localização deste atol, as ilhas foram em grande parte poupadas da depredação humana. Visando uma amostragem abrangente da diversidade entomofaunística do local e uma caracterização geral do nicho trófico dos insetos, foram realizadas três coletas $(1994,1995,1996)$ com vários métodos. Foram capturados 1.606 insetos pertencentes a oito ordens: 1 . Coleoptera - foram coletados 333 exemplares pretencentes às famílias Dermestidae (Dermestes cadaverinus), Tenebrionidae (Phaleria testacea e outra morfoespécie) e Curculionidae (uma morfoespécie); 2. Dermaptera - foram coletados 50 exemplares da família Carcinophoridae (Anisolabis maritima); 3. Diptera - foram coletados 281 exemplares pertencentes às famílias Ephydridae (Scatella sp. e Hecamede sp.) e Hippoboscidae (uma morfoespécie); 4. Hymenoptera - foram coletados 45 exemplares de Formicidae (Brachymyrmex sp.); 5. Lepidoptera - foram coletados 111 exemplares de Microlepidoptera (uma morfoespécie); 6. Mallophaga - foram coletados 18 exemplares em aves (duas morfoespécies); 7. Orthoptera - foram capturados 237 exemplares da família Acrididae (Schistocerca cancelatta), Tridactylidae (uma morfoespécie) e Blatidae (três morfoespécies); e 8. Thysanoptera - foram coletados 531 exemplares (uma morfoespécie). Também foram coletados 112 exemplares da Classe Arachinida. A Ordem Araneae foi representada pelas seguintes famílias: 1. Miturgidae (Cheiracanthium inclusum); 2. Saltididae (duas morfoespéciese); 3. Segestridade (Ariadna sp.); e 4. Theridiidae (Achaearanea sp. e Latrodectus geometricus). Para a ordem Scorpionida, foram coletados somente representantes da família Buthidae (Isometrus maculatus). Segundo observações no ato das coletas, a maioria dos insetos é detritívora e/ou necrófaga, o que sugere que a dimensão do nicho trófico dos insetos esteja em função de dejetos e cadáveres de aves. Foi constatada uma baixa diversidade na entomofauna do atol, pois, as varreduras minuciosas nas duas ilhas constataram que, no período da coleta, a diversidade mostrou-se restrita a 25 morfoespécies.

Palavras-chave: Atol das Rocas, fauna entomológica insular, nicho trófico.

\section{INTRODUCTION}

For Leinz \& Leonardos (1970), the term atoll means a coral reef in the shape of a ring with an internal small lagoon that flows to the sea through channels. The Atol das Rocas is a singular environment, the only atoll in the South-western Atlantic Coast and the first marine conservation unit developed in Brazil.

Since the Atol das Rocas is located almost a hundred fifty miles from Natal, RN, the main city nearby, and the access to it is difficult due to real barriers of the coral reefs, there are only few studies on this atoll, none of them dedicated to the entomological fauna. After 1991, the Instituto Brasileiro do Meio Ambiente e dos Recursos
Renováveis (IBAMA) made all efforts to implement a research base in the atoll, and for the time being many different studies are in being carried out.

With reference to the other atolls, the literature on this particular subject has many recent studies on the entomological fauna, such as the entomological survey of the Handson Islands, in the Pacific ocean carried out by Benton (1995), and the heteropterofauna survey of the Aldabra atoll in the Indian Ocean conducted by Polhemus (1993).

Marinoni \& Dutra (1991) observed that a variety of ecosystems had already deteriorated when the fauna and flora diversity began to be studied in a proper way. This lack of studies in Brazil is also emphasized by other authors: VarellaFreire et al. (1995), in a published entomological 
study of the semiarid area of Ecological Station in Seridó, RN, observed that there were no entomological studies at all in the Rio Grande do Norte State; Marinoni \& Dutra (1991) and Dutra \& Marioni (1994), in their studies on the entomological fauna of the Paraná State and Ilha do Mel, pointed out the importance of faunal knowledge for the biodiversity conservation and the consequent stockpile for future replenish.

The present study aims to describe the entomological diversity and the general trophic niche of atoll's entomofauna, as the ecological site and peculiarities of Atol das Rocas made it necessary to develop researches in its multiple aspects.

\section{MATERIAL AND METHODS}

\section{Study field}

Bastos \& Sales (1994), mention the following biogeographical aspects of Atol das Rocas: located in the north-eastern region of the country, 144 miles $(266 \mathrm{~km})$ away from the city of Natal, and 80 nautical miles from the Fernando de Noronha's archipelago (geographic co-ordinates: $3^{\circ} 51^{\prime} \mathrm{S}$ and $33^{\circ} 49^{\prime} \mathrm{W}$ ); the atoll has a volcanic origin and coraline formation; the reef, in its ellipsoid shape, is nearly circular in its largest axis (E-W) - approximately $3.7 \mathrm{~km} \mathrm{(2}$ miles) long - and the shortest axis is $2.5 \mathrm{~km}$ long. Inside the reef ring, there are two islands: Ilha do
Farol and Ilha do Cemitério, both encompassing 7.2 $\mathrm{km}^{2}$ of emerged area (Fig. 1); the climate is typically equatorial and the rainy seasons occur from March to July; the soil structure is made of organic deposits, full of calcium oxide and carbon dioxide; the islands' vegetation is basically formed by six families: Portulacaceae, Gramineae, Amaranthaceae, Cyperaceae, Palmaceae and Casuarinaceae.

According to Leão (1990) and Leão et al. (1991), the atoll's reefic ring is formed basically by thick crusts of coraline algae and predominantly for one species of coral (Siderastrea stellata); in the west side of reefic ring there are two islands formed by three distinct terraces, the oldest of which reaches three meters high. The authors also observed that the soil contains a large number of reefic sediment, such as coraline algae, foraminifera (particularly Homotrema rubrum), and a sort of corals and mollusks. They also point out that during the high tides almost the whole reef remains underwater; in the low tides, a big part of it emerges. Kikuchi (1994) mentioned that the reef substrate of Atol das Rocas accumulated above volcanic rocks was formed during the Tertiary period.

Schuls-Neto (1992), reported that in the two small islands there are 143,000 birds, mostly represented by the Sula dactylatra, S. leucogaster, Anous minutus, A. stolidus and Sterna fuscata, which depend on atoll for their reproduction, rest and feeding.

Ring of Coral reef

Lagoon

Ilha do Farol

Ilha do Cemitério

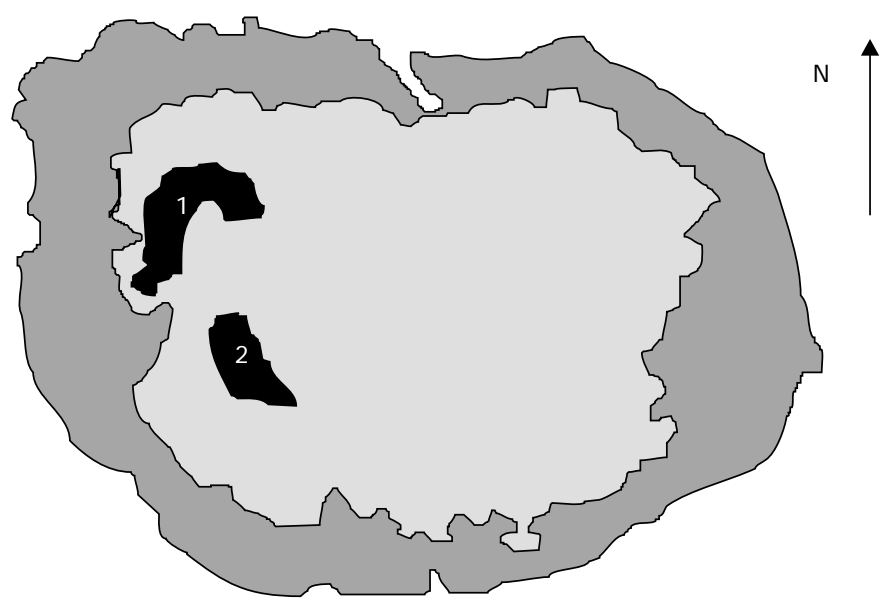

Adapted of Leão (1990)

$1000 \mathrm{~m}$

Fig. 1 - Photointerpreted map of Atol das Rocas. 


\section{Collected and examined material}

In 1994, IBAMA (without dating the collect) donated manually collected samples which were examined together with the material, also manually collected, in August, 1995.

Throughout the month of September, 1996, diurnal and overnight collects were carried out with the help of an entomological net. A bright trap described in Borror \& De Long (1969) was also used together with traps for detritophagous insects adapted from Xerez (1992). For this last collect, guts of dead birds were used as baits. The collected material was stored for transportation in an alcohol solution (70\%). In 1996, meteorological measurements were recorded as well (Table 1).

During the collects, the ecotopes were observed, and the circadian activity of a particular taxon (Thysanoptera) was followed through of its counting in flowers collected in different hours of the day, for five days.

For the collecting of the ectoparasite entomofauna, it was necessary to catch 14 birds of different species, which were bagged till the neck and cotton balls soaked with ether were introduced inside the bag. Such technique allowed the collect of ectoparasites without damaging the bird.

The collected insects were incorporated to the Entomological Collection of Instituto Oswaldo Cruz (Rio de Janeiro State, Brazil) and also sent to the Departamento de Estudos Oceanográficos de Natal (Rio Grande do Norte State, Brazil). The arachnids were sent to the Instituto Butantan (São Paulo State, Brazil), to Centro Universitário de Barra Mansa, UBM (Rio de Janeiro State, Brazil), and to the Museu Nacional do Rio de Janeiro (Rio de Janeiro State, Brazil).

\section{On taxa}

In the field, the insects were separated according to their orders. In laboratory, they were appropriately pinned and tagged for better conservation.

Then, the insects were separated in morphospecies, a great part of them at the family level, according to the taxonomic criteria proposed by Borror \& De Long (1969). For the arachnids the sorting procedures were the same, however, they were kept in an alcohol solution (70\%). For further inference on biodiversity, the methodology proposed by Oliver \& Beattie (1996) was applied through the use of morphospecies rather than species identified by system experts.

\section{RESULTS}

The total collect comprehends 1,606 insects and 112 arachnids. Since the purpose of the present study was only the characterization of entomofauna, many morphospecies that had already been collected before, or that were accidentally caught by the traps, were released to avoid possible damages to the already fragile environment. The greatest biomass of insects was manually collected from dead birds. In the entomological net it was found lepidopterous, dipterous, and ortopterous. The bright trap proved to be inefficient on windy conditions. The trap for detritophagous insects proved to be of relative efficiency, nevertheless this method was useful for selecting necrophagous insects. The number of collected samples, as well as other information about the insects are shown in Table 2. The data concerning the arachnids can be found in Table 3 .

TABLE 1

Meteorological data (September, 1996).

\begin{tabular}{|c|c|c|c|c|}
\hline \multirow{2}{*}{ Timetables } & \multicolumn{2}{|c|}{ Temperature ('C) } & \multicolumn{2}{c|}{ Relative air humidity (\%) } \\
\cline { 2 - 5 } & $\mathbf{9 : 0 0}$ & $\mathbf{1 7 : 0 0}$ & $\mathbf{9 : 0 0}$ & $\mathbf{1 7 : 0 0}$ \\
\hline$\overline{\mathrm{X}}$ & 29.08 & 28.48 & 80.12 & 79 \\
\hline Max. & 31 & 31 & 91 & 91 \\
\hline Min. & 25 & 26 & 67 & 68 \\
\hline S & 1.52761 & 1.55777 & 7.45162 & 8.17461 \\
\hline
\end{tabular}


TABLE 2

Insects collected in Atol das Rocas.

\begin{tabular}{|c|c|c|c|}
\hline Order & Famil & Species or morphospecies (mp.) number & $\begin{array}{c}\text { Total } \\
\text { collected }\end{array}$ \\
\hline \multirow{4}{*}{ 1. Coleopter } & \multirow[t]{2}{*}{ Tenebrionidae: } & Phaleria testacea & \\
\hline & & $1 \mathrm{mp}$ & \\
\hline & Dermestidae & Dermestes cadaverinus & 333 \\
\hline & Curculionidae & $1 \mathrm{mp}$. & \\
\hline 2. Dermapter & Carcinophoridae & Anisolabis maritima & 50 \\
\hline \multirow{3}{*}{ 3. Dipter } & \multirow[t]{2}{*}{ Ephydridae: } & Hecamede sp. & \\
\hline & & Scatella $\mathrm{sp}$ & 281 \\
\hline & Hippoboscidae & $1 \mathrm{mp}$ & \\
\hline 4. Hymenopter & Formicidae & Brachymyrmex sp. & 45 \\
\hline 5. Lepidopter & - & $1 \mathrm{mp}$ & 111 \\
\hline 6. Malloph & - & $2 \mathrm{mp}$ & 18 \\
\hline \multirow{4}{*}{ 7. Orthopter } & \multirow[t]{2}{*}{ Blattidae } & Periplaneta americana & \\
\hline & & $2 \mathrm{mp}$ & 237 \\
\hline & Acrididae & Schistocerca cancellata & \\
\hline & Tridactylidae & $1 \mathrm{mp}$ & \\
\hline 8. Thysanopter & - & $1 \mathrm{mp}$ & 531 \\
\hline
\end{tabular}

TABLE 3

Arachnids collected in Atol das Rocas.

\begin{tabular}{|c|c|c|c|}
\hline Order & Family & Species or morphospecies (mp.) number & Total collected \\
\hline \multirow{4}{*}{ 1. Araneae } & Miturgiade & Cheiracanthium inclusum & \\
\cline { 2 - 4 } & Theridiidae & Achaearanea sp. & \\
\cline { 2 - 4 } & & Latrodectus geometricus & \\
\cline { 2 - 4 } & Segestriidae & Ariadna sp. & \\
\cline { 2 - 4 } & Salticidae & $2 \mathrm{mp}$. & 45 \\
\hline 2. Scorpionida & Buthidae & Isometrus maculatus & \\
\hline
\end{tabular}

According to their taxonomic composition, the number of morphospecies and other ecological remarks are related as follows:

\section{I) INSECTA:}

\section{Coleoptera}

Four morphospecies belonging to three families of this order widely spread in the atoll were registered: 1 . Tenebrionidae - represented by a morphospecies largely collected next to the human lodging and also present under dead birds and
Phaleria testacea, always seen next to sea-shore; 2. Dermestidae -Dermestes cadaverinus, in their larval and adult phases, were observed in dead bodies of birds, accelerating the decomposition process; 3. Curculionidae - they were introduced together with the human provisions, they were always in the human lodgings' dispensary. The distribution of this species in Atol das Rocas is apparently restricted to the anthropic environment as there were no appropriate throphic resources in the natural environment. 


\section{Dermaptera}

Anisolabis maritima (Carcinophoridae) was the only dermapterous collected in the atoll. Abundantly present, they live together with the coleopterous in dead bodies of birds. It was observed in field that this species eats larvae of Dermestes cadaverinus by attacking their inferior part of abdomen, where they are most fragile.

\section{Diptera}

Three morphospecies of two families were collected: Hippoboscidae and Ephydridae. The Hippoboscidae was collected in Sula dactilatra. They occasionally visited the human lodging, but their feeding activities in humans were not observed.

The two species of Ephydridae known as shore flies (Krivosheina, 1995) belong to the Hecamede and Scatella genera. The first ones were collected in dead birds and during the beginning of the decomposition process the abundant presence of larva was observed. The latter were collected from small ponds of rainwater (an artificially constructed cistern); they were also collected from Portulacaceae flowers.

\section{Hymenoptera}

Brachymyrmex sp. (Formicidae) specimens were collected under coconut palms in the atoll, where ants' nests are largely found. These specimens were also found under dead birds.

\section{Lepidoptera}

These microlepdopterous were largely found on Portulacaceae flowers. They were constantly "fighting" against the strong wind that blows every night and day in the atoll. According to personal communication from IBAMA, an overpopulation of these insects has been observed in recent years, but there is no accurate data to prove such information. Through observations, not based on statistical parameters, apparently from 1995 to 1996, the local population did not present oscillation of its dynamics.

\section{Mallophaga}

Two concomitant morphospecies were collected in Sterna fuscata and Anous stolidus.

\section{Orthoptera}

The ortopterous are represented by morphospecies belonging to three families: 1 .
Acrididae - Schistocerca cancellata are frequent in Grammineae and Cyperaceae. They usually jump and fall into the sea. In the low tide, it was observed that many of them simulate they are swimming by stretching their hindfeet and grasping the corals in order to return, but in high tides they hardly ever come back; 2. Blattidae - The Periplaneta americana is the most frequently seen species, and it always appears in the human lodging. Although the presence of the de $P$. americana has been identified throughout the two islands, this species is much more frequent in the surroundings of the human lodging. Two other morphospecies were collected. Their predominance was regarded near the coconut palms and in the vegetation. These morphospecies were not observed abundantly near the human lodgings, thus demonstrating its less anthropophilic habits; 3 . Tridactylidae They were collected manually at night.

\section{Thysanoptera}

One morphospecies was collected on Portulacaceae flowers. The Portulacaceae present circadian phenology when their flowers open, and it seems that Thysanoptera follows this phenology synch. On the same day 100 flowers were collected at three different hours: at 10:00 AM (temperature: $\overline{\mathrm{X}}=30^{\circ} \mathrm{C} / 86^{\circ} \mathrm{F}$ ), 39 samples were collected; at $12: 00$ $\mathrm{AM}$ (temperature: $\overline{\mathrm{X}}=30.5^{\circ} \mathrm{C} / 86.9^{\circ} \mathrm{F}$ ), 73 samples were collected; and at 3:00 PM (temperature: $\overline{\mathrm{X}}=$ $\left.28.9^{\circ} \mathrm{C} / 84.02^{\circ} \mathrm{F}\right) 21$ samples were collected.

\section{II) ARACHNIDA:}

\section{Araneae Order}

Specimens of the following families were collected: 1. Miturgidae -16 samples of Cheiracanthium inclusum; 2 . Salticidae - 13 samples of two morphospecies; 3 . Theridiidae -6 young specimens of the Achaearanea sp. and 32 of Latrodectus geometricus; 4. Segestridade - one adult male of Ariadna sp.

\section{Scorpionida Order}

45 samples of Isometrus maculatus (Buthidae) were collected among young and adults.

\section{DISCUSSION}

The insular fauna draws one's attention for its geographical isolation, mainly, to the invertebrates as they are incapable of dispersing. Some peculiar characteristics of the atoll, besides its 
remote location, must be here highlighted in terms of genetic differentiation caused by geographical aspects. Kikuchi (1994) mentions the geographical aspects of the atoll, but there are no data that could clear out the approximate age in which the terrestrial biocoenoses may have been established in the atoll. Since a high rate of synanthropic species was noticed, there is reason to suppose that terrestrial fauna is recent and that a big part of the entomofauna has been introduced by anthropic activities, such shipwrecks, fishing boats, or during a shift in the researchers' teams. The small size of the islands, as well as its low supporting capacity, implies in a reduced number of insects in this ecosystem. Thus, a reintroduction would have a great influence in the established gene-pool of the atoll; nevertheless, mutations with a low selective rate would have strong influence in these islands.

The ecological homogeneity derives from the low levels of diversity and phitomass revealed by the vegetation, which constrains the trophic resources. It was also observed that the environment is hostile as there are no shades at all and no sources of fresh water. Thus the barriers put by those ecosystem characteristics may contribute to maximize genetical discrepancies between the atoll and continent's entomofauna, serving as pressure factors for the selection of genotypes with adaptive rates to this environment. As Futuyma (1992) once remarked, the reintroductions can contribute to homogenize the genetic pool of an ecosystem and this may happen with the synanthropic species introduced in Atol das Rocas.

Oliver \& Beattie (1996) carried out a comparative analysis of methods for assessing the biodiversity. They used species identified by system experts and morphospecies identified by nonexperts. Their results were similar in terms of the evaluation of species - or morphospecies-based biodiversity, which means that an accurate approach to the morphospecies makes the biodiversity evaluation of an ecosystem possible. Through the use of morphospecies, our research show the low entomological diversity of Atol das Rocas, with its 25 morphospecies comprehending insects and arachnids. Probably, the phenomenon derives from the grounding effect, the small size of the islands, the environmental hostility, and their great distance from the continent.
Apparently the dimension of the entomofauna's trophic niche is strictly related to the ornithofauna, meaning that a big part of the entomofauna is constituted by necrophagous. Some taxa of the atoll's entomofauna were found in similar situations by other authors: Chelazzi \& Colombini (1989) observed the frequent presence of species of Phaleria in dead birds; they assured that this insect has an important role in the consume of putrid meat. Ecological aspects concerning this taxon are also available in Tongiorgi (1969). Plaisier (1994) mentioned that coleopterous are frequent in rich environment in sea-birds nests due to high density of carcasses of birds. Taglianti (1995) remarked that A. maritima is a cosmopolitan species, living in beaches where they show high level of adaptability. Ciampolini \& Suss (1994) wrote that species of Scatella (S. stagnalis Fallen) also look for cisterns with decomposed plants on which its larvae feed. According to Dlusskii (1993), species of Brachymyrmex, as B. heeri, are anthropophilic and frequently introduced in islands on an anthropic basis. Peck \& Roth (1992) carried out a survey of the cockroaches in the Galapagos Islands, and they also noticed the introduction of other species of Periplaneta genera (P. australasiae and P. brunnea). There's no doubt that the $P$. americana was introduced by man and that probably it is still being introduced nowadays, as there are a lot of them in port areas.

Acknowledgments - To Instituto Brasileiro do Meio Ambiente and to Centro Universitário de Barra Mansa for all support. To Prof. Elaine Folly Ramos and to Dr. Antônio D. Brescovit for the identifications of the aracninds.

\section{REFERENCES}

BASTOS, P. C. R. \& SALES, G., 1994, A Reserva Biológica do Atol das Rocas, IBAMA, 13p.

BENTON, T. G., 1995, Biodiversity and biogeography of Henderson Island's insects. Biological Journal of the Linnean Society., 56(1-2): 245-259.

BORROR, D. J. \& DE LONG, D., 1969, Introdução ao Estudo dos Insetos. Editora Edgard Blücher, São Paulo, 653p.

CHELAZZI, L. \& COLOMBINI, I., 1989, Zonation and activity of two species of genus Phaleria Latreille (Coleoptera, Tenebrionidae) inhabiting an equatorial and a Mediterranean sandy beach. Ethology Ecology \& Evolution, 1: 313-321. 
CIAMPOLINI, M. \& SUSS, L., 1994, Scatella stagnalis Fallen (Diptera Ephydridae) on horticultural crops and flowers under greenhouse. Bollettino di Zoologia Agraria e di Bachicoltura, 26(1): 115-126.

DLUSSKII, G. M., 1993, Ants (Hymenoptera: Formicidae) of Fuji, Tonga, and Samoa and the problem of island faunas formation 1. The problem. Zoologicheskii Zhurnal, 72(5): 66-76.

DUTRA, R. R. C. \& MARINONI, R. C., 1994, Insects captured with Malaise trap at the "Ilha do Mel", Baía de Paranaguá, Paraná, Brazil. I. Ordinal composition. Revista Brasileira de Zoologia, 11(2): 227-245.

FUTUYMA, D. J., 1992, Biologia evolutiva. Sociedade Brasileira de Genética/CNPq, $2^{\text {nd }}$ ed., 646p.

KIKUCHI, R. K. P., 1994, Geomorfologia, estratigrafia e sedimentologia do Atol das Rocas (Rebio/Ibama/RN), Atlântico Sul Ocidental Equatorial. Tese de Pós-graduação em Geologia, Universidade Federal da Bahia.

KRIVOSHEINA, M. G., 1995, Zoogeography of some shore-flies from Northern Europe and Siberia (Diptera, Ephydridae: Parydrinae and Ephydrinae). Acta Zoologica Fennica., O(199): 29-31.

LEÃO, Z. M. A. N., 1990, Comportamento geoambiental, caracterização morfoestrutural e história do Atol das Rocas. Projeto para o Curso de Pós-Graduação, Universidade Federal da Bahia, Salvador, 8p.

LEÃO, Z. M. A. N., CERQUIRA-NETO, J., KIKUCHI, R. K. P. \& SANTOS, L. M., 1991, Geologia e Geofísica no Atol das Rocas. Relatório de Atividades, Universidade Federal da Bahia, Salvador, 11p.

LEINZ, V. \& LEONARDOS, O. H., 1970, Glossário geológico. Editora da USP, São Paulo, 236p.

MARINONI, R. C. \& DUTRA, R. R. C., 1991, Survey of the entomological fauna in Parana State: I. Introductory Part: On climatic and floristic conditions in eight collecting sites: Faunistic data from August/1986 to July/1987. Revista Brasileira de Zoologia, 8(1-4): $31-73$

OLIVER, I. \& BEATTIE, A. J., 1996, Designing a costeffective invertebrate survey: A test of methods for rapid assessment of biodiversity. Ecological Applications, 6(2): 594-607.
PECK, S. B. \& ROTH, L. M., 1992, Cockroaches of the Galapagos Islands, Ecuador, with descriptions of three new species (Insecta: Blattodea). Canadian Journal of Zoology, 70(12): 2202-2217.

PLAISIER, F., 1994, The significance of the carrion beetles (Silphidae, Coleoptera) in the breeding areas of the herring gull (Larus argentatus) on a dune island of the southern North Sea. Entomologische Blaetter fuer Biologie und Systematik der Kaefer, 90(1-2): 99-104.

POLHEMUS, D. A., 1993, The Heteroptera of Aldabra Atoll and nearby islands, western Indian Ocean, Part 2: Freshwater Heteroptera (Insecta): Corixidae, Notonectidae, Veliidae, Gerridae and Mesoveliidae. Atoll Research Bulletin, O(381): 1-9.

SCHULS-NETO, A., 1992, Anilhamento de Aves na Reserva Biológica do Atol das Rocas, Anais do IX Encontro de Zoologia do Nordeste.

TAGLIANTI, A. V., 1995, The Dermaptera of circumsardinian islands. Annali del Museo Civico di Storia Naturale "Giacomo Doria", 90(0): 529-552.

TONGIORGI, P., 1969, Ricerche ecologiche sugli artropodi di una spiaggia sabbiosa del Litorale Tirrenico III. Migrazoni e ritmo de attivita locomotora nell'isopode Tylos laterelli (Aud. \& Sav.) e nei tenebrionidi Phaleria provincialis Fauv. e Hammobia pellucita Herbst. Redia., 51: 1-19.

VARELA-FREIRE, A. A., ANDRADE, H. T., ROCHANETO, M., COSTA, L. V. N. \& Oliveira, M. F., 1995, Levantamento Entomofaunístico da Estação Ecológica do Seridó, Serra Negra do Norte, RN. Revista de Biociências, UFRN, 1(1): 35-48.

XEREZ, R., 1992, Estudo Comparativo da Hymenopterofauna detritivora de duas unidades fisiogeográficas da Restinga de Marambaia (Baía de Sepetiba, Rio de Janeiro, RJ). Thesis, UFRRJ, p. 47. 